Review

\title{
Are Cover Crops Affecting the Quality and Sustainability of Fruit Production?
}

\author{
Giovanna Giacalone ${ }^{1, *(\mathbb{D}}$, Cristiana Peano ${ }^{1}\left(\mathbb{D}\right.$, Deborah Isocrono $^{1}(\mathbb{B})$ and Francesco Sottile ${ }^{2}(\mathbb{C})$ \\ 1 Department of Agricultural, Forest and Food Sciences (DISAFA), University of Torino, Largo Paolo Braccini, \\ 3, 10195 Grugliasco, Italy; cristiana.peano@unito.it (C.P.); deborah.isocrono@unito.it (D.I.) \\ 2 Department of Architecture (DARCH), University of Palermo, Viale delle Scienze, 11, 90128 Palermo, Italy; \\ francesco.sottile@unipa.it \\ * Correspondence: giovanna.giacalone@unito.it
}

Citation: Giacalone, G.; Peano, C.; Isocrono, D.; Sottile, F. Are Cover Crops Affecting the Quality and Sustainability of Fruit Production? Agriculture 2021, 11, 1201. https://doi.org/10.3390/ agriculture11121201

Academic Editor: Sally Bound

Received: 2 November 2021

Accepted: 26 November 2021

Published: 29 November 2021

Publisher's Note: MDPI stays neutral with regard to jurisdictional claims in published maps and institutional affiliations.

Copyright: (c) 2021 by the authors. Licensee MDPI, Basel, Switzerland. This article is an open access article distributed under the terms and conditions of the Creative Commons Attribution (CC BY) license (https:// creativecommons.org/licenses/by/ $4.0 /)$.

\begin{abstract}
The study of the interaction between fruit trees and cover crops has been addressed in numerous works over the last 50 years or more, evidencing the need to evolve from a productive orchard to an orchard that plays different ecosystem roles in terms of environmental sustainability rather than just productivity. This review, through an analysis of the scientific literature since the 1950s, highlights the development of sustainable soil management models in fruit tree orchards, mostly considering the relationship with fruit quality traits and with the ecosystem services that result from the adoption of cover crops, aiming at identifying and formulating technical recommendations in perennial orchards. Cover crop management surely improves soil features and positively influences fruit quality in perennial woody species, but also helps to develop a better habitat for beneficial insects, thus influencing pollination. A large number of scientific approaches highlight the beneficial use of a mixture of seeds in order to enhance biodiversity, aiming at improving ecosystem services for a transition towards more sustainable systems based on agroecological management.
\end{abstract}

Keywords: cover crops; fruit orchards; quality; sustainability; ecosystem services

\section{Introduction}

A cover crops is defined as a "close-growing crop that provides soil protection, seeding protection, and soil improvement between periods of normal crop production, or between trees in orchards and vines in vineyards" [1]. This definition indicates a number of benefits deriving from the application of soil management models which have, however, found discontinuous application in orchards due to different interpretations of the direct effects on production and fruit quality [2,3]. Soil management is, in fact, one of the key practices that influences the vegetative and reproductive activity of an orchard [4,5]. Nowadays, all aspects related to the sustainability of fruit systems are of increasing importance and involve all stakeholders, i.e., farmers, technicians, and those who determine agricultural policies $[6,7]$. Cover crops play an increasingly recognized role in models of sustainable management, favoring conservation of soil and its fertility, water, organic matter, and biodiversity. Inter-row grassing of orchards is a very common condition in modern orchards. Numerous works have documented and highlighted the advantages and disadvantages of different soil management techniques. Since the 1950s, there has been considerable interest in studying the management of orchard soil, considering all the possibilities offered from non-processing, to mechanical processing, to spontaneous grassing up, to the sowing of turf [8].

There has been an evolution regarding the aspects investigated. In fact, while in older works the focus was on the competition between plants and the effect on production, more recently, environmental aspects are also analyzed together with inter-row and tree row management $[9,10]$, and the role of margins and flower strips, which offer protection and nourishment to beneficial insects and pollinators, assumes importance (Figure 1). 


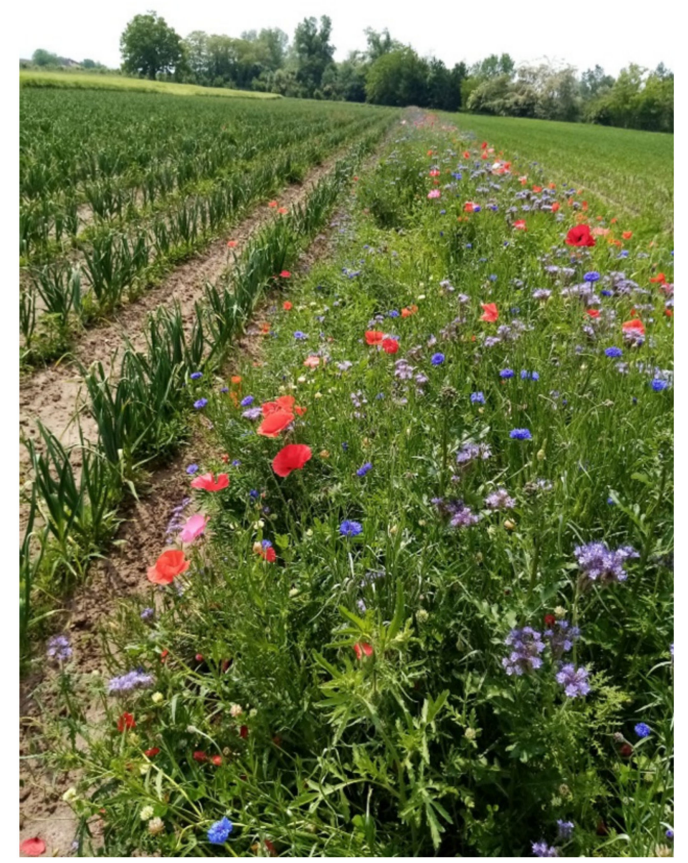

Figure 1. Flower strip in garlic cultivation in Piedmont.

Although the management of the turf is at the center of the most advanced studies, soil management is studied in orchard systems with the aim of increasing biodiversity; enhancing soil fertility from the agronomic, chemical, and biological points of view; and reducing chemical treatments, thus promoting a sustainable environment [11]. Increased consumer demand for more natural products and greater attention to the environment has led to greater sensitivity towards environmental sustainability [12,13], evidencing more attention to reducing the inputs that occur in a balanced system. As regards the adoption of cover crops, it is possible to identify this conceptual evolution: the grassing of orchards has gone from being a limit due to the competition with fruit plants, to being a resource to increase biodiversity.

Cover crops are able to improve soil quality in terms of physical, chemical, and biological properties both in the short and long term. In fact, they induce an increase in organic matter and in the amount of mineral elements, with a clear and positive alteration of the microbial component of the soil [14]. Over the years, in different fruit regions, tillage, green covers (permanent or temporary), herbicide applications, and mulching have all been used with different objectives and results. In early studies, attention was placed on the effect of grassing down on the agronomic characteristics of soil and on the competition between orchards and grass [15]. A grass sward has the immediate practical advantage of providing a convenient working surface for all orchard operations, while the inter-row grassing results in a growth reduction, mainly in young trees. This is due to the competition for water and nutrients, mainly nitrogen. Greenham [16] observed that grassing down had beneficial long-term effects on soil fertility. However, trials of grassing carried out in the 1960s had a negative effect on the growth of young orchards of several fruit trees species due to excessive competition for water and nutrients [17,18]. Therefore, it has been proven that the grassing of orchards is possible only when adequate water for irrigation is available, overall in dry environmental conditions [14,19]. As well as this, experiments with Cox's Orange apple found that competition in the first year persisted in the following years by determining a reduction in vigor [20] because, in "grassed" soils, the roots developed up to the soil surface, and the root systems of trees grown in "grassed" soils were more extensively developed than those grown in tilled soils [21,22]. Fruit yield was also evaluated: it was greater without any cover crop but, in the grassed sections, the fruit ripened earlier. 
Through an analysis of the scientific literature from the last 50 years, this review aims to provide synthesis elements mostly highlighting the relationship between the quality characteristics of fruit and the ecosystem services strongly linked to the adoption of cover crops. The objective is to identify elements of useful deepening to formulate technical recommendations for soil management in orchards in view of a transition towards more sustainable systems based on agroecological management. The quantitative and qualitative analysis of the literature considered for this study is shown in Figure 2. It is clear that the number of scientific papers that have been carried out on this topic has grown over the years, also changing the focus and developing, especially in recent years, many insights addressed to strengthening sustainable technical choices.



Figure 2. Quantitative and qualitative analysis of the recorded literature, evidencing each period and specific focuses. The total refers to the output coming from different sources by using the keywords 'cover crops' and 'quality'. In the brackets are the sources of the review.

\section{Fruit Quality in Relation to Cover Crops}

The issue of fruit quality in relation to soil management has been investigated since the early 1950s. Grassing, in fact, is able to determine some changes in fruit quality, starting from the skin color. Greenham [16] highlighted the role of cover crops to improve the skin color and to reduce pre-harvest fruit drop. As confirmed by later studies [23,24], it resulted in a higher fruit commercial value and appeared to be attributed to the different vigor of the plants, which also determined a reflective effect of solar radiation in the lower part of the canopy [25]. With the same extent, a light-reflecting effect of turf has also been noted as affecting fruit quality. In addition, due to the different vegetative behavior of cultivated plants, grassing was able to induce later flowering, due to which trees could more easily escape late frosts [23,26,27]. Fruit mineral composition was positively affected [27-29], mostly due to a lower nitrogen content and higher $P, K$, and Ca concentration $[16,27,30,31]$. Both $\mathrm{P}$ and $\mathrm{K}$ were gradually released with the decomposition of mowed grass left on soil [32], then they appeared more mobile.

Competition for water and nutrients considerably influences the development of the plant, its maturity, fruit ripening, yields, and quality, mostly due to different behavior in terms of the tree vigor [33,34]. Many positive effects have been evidenced, in terms of fruit skin color distribution, sugar accumulation [35], and flowering induction [36]. The reduction in vigor, moreover, allows trees to obtain a more compact canopy with reduced competition between vegetative organs and fruits for the translocation of nutrients from the roots to the aerial part [34]. The effect of the competition exerted by cover crops is not always positive. Several authors, in fact, have shown that partial or total cover determines a reduction in production on pear, apple, and peach trees compared to tilling 
or weeding, with a corresponding positive effect on fruit size [19,37-43]. A negative effect of cover crops on yield has been observed on grapevines [44], although a comparison between soil under conventional management and artificially grassed soil showed no significant differences regarding quantity and quality of production, as well as in case of water shortage, where a reduction in plant vigor, but not in production quantity, was registered [45]. The same behavior appeared in peaches and apples [46] when comparing different soil management approaches.

As regards fruit quality, soluble sugars, titratable acidity, and pulp firmness at ripening, as well as the total phenolic contents, have been studied and showed results which were not always unambiguous. Gormeley et al. [47] on Cox's Orange Pippin and Red Jonathan apples from orchards with different soil management techniques (grassed, mechanically tilled, and weeded), found lower yields on grassed plots for both cultivars, and grassing improved the Cox's Orange Pippin apple quality only marginally, even in more recent experiments [48]. From a gustative perspective, panels did not show a clear preference for fruits of a specific treatment, probably because the sugar contents of apples from the different soil management conditions were comparable anyhow. Similar results were revealed in Golden Delicious apples, with higher quality and better panel in fruits from the grassed plots $[49,50]$. Appropriately managed sub-row grassing positively affected some quality parameters also in peaches, such as flesh texture, soluble solids content (SSC), and dry matter content [20], evidencing the opportunity to associate biodiversity while avoiding any negative effects on either tree growth or fruit yield and quality.

Different management methods were also applied on blackberries [51], where manual weeding, total grassing (non-weeded), and mulching with a weed mat were compared. Weed management had no effect on the $\mathrm{pH}$, titratable acidity, and soluble solids content of the fruit, while it was found to have a significant effect on total phenols, monomeric anthocyanins, ORAC, FRAP, sugar profile, and aromatic intensity. In particular, weeding in the row resulted in a higher content of antioxidants with higher antioxidant capacity in early harvests while, in late harvests, the fruits of totally grassed areas provided the highest values. Mulching with a weed mat always gave the worst values for all parameters considered [51].

In vineyards, the effect of cover crops has been widely studied in relation to the quality of the product at harvest (Figure 3). The competition was shown to positively affect grape and must quality, increase soluble solids, anthocyanin content, and phenolic components in the vine and decrease titratable acidity and $\mathrm{pH}$ [52]. These results were confirmed for Sangiovese vines, for which a higher polyphenol content was measured in wines produced from grapes obtained from grassed rows compared to those produced from grapes obtained from tilled rows $[53,54]$. In general, cover crops reduce the nitrogen levels in grape juice by up to $16 \%$ compared to those from a conventionally tilled vineyard [55]. In some cases, particularly for white grape varieties, this reduction could determine a detriment of digestion by yeasts [56] with a possible alteration of fermentation and many negative effects on the aromatic complex [57].

More recently, the attention of research has been focused on the effect of seed mixture and the duration of grassing on fruit quality. A study on pear trees has shown that, after a long period, spontaneous grassing can bring advantages in fruit texture, soluble solids, total aroma, and acid-sugar ratio. In fact, all these parameters were better in pears derived from orchards naturally grassed for 4 to 7 years than in orchards grassed for only 2 years [58]. Different types of soil cover (herb lay, ryegrass, red clover, and compost), on the other hand, determined changes in the quantity and quality of yields in Braeburn and Royal Gala apple orchards. Specifically, there was a significant increase in yield when cover crops were realized with red clover compared to herb lay or ryegrass. Clover also favored a greater accumulation of $\mathrm{N}$ in the fruits, thus modifying the vegetative-productive balance and determining a delay in harvesting. The sugar content was lower in red clover than in other treatments, while all types of grasses were found to be better than compost in terms of calcium levels in the fruits [59]. These results have been confirmed by several studies on 
apples, especially when the vegetation cover is made with legumes, with a natural increase in the soil nitrogen content available to the plant [60] also determining lower soluble solids content and lower pulp firmness [59,61]. Wheeler and Pickering [62] reported a marked reduction in juice ammonia levels in grapes grown with chicory (Chichorium intybus) competition compared to bare or tilled soil. Muscas et al. [63] showed different effects on must quality in plots artificially grassed with a mixture of grasses, where musts had a higher content of sugars, anthocyanins, and polyphenols; in plots grassed with a mixture of legumes and in those with natural grassing, a reduction in total polyphenols and anthocyanins, respectively, was observed [64].

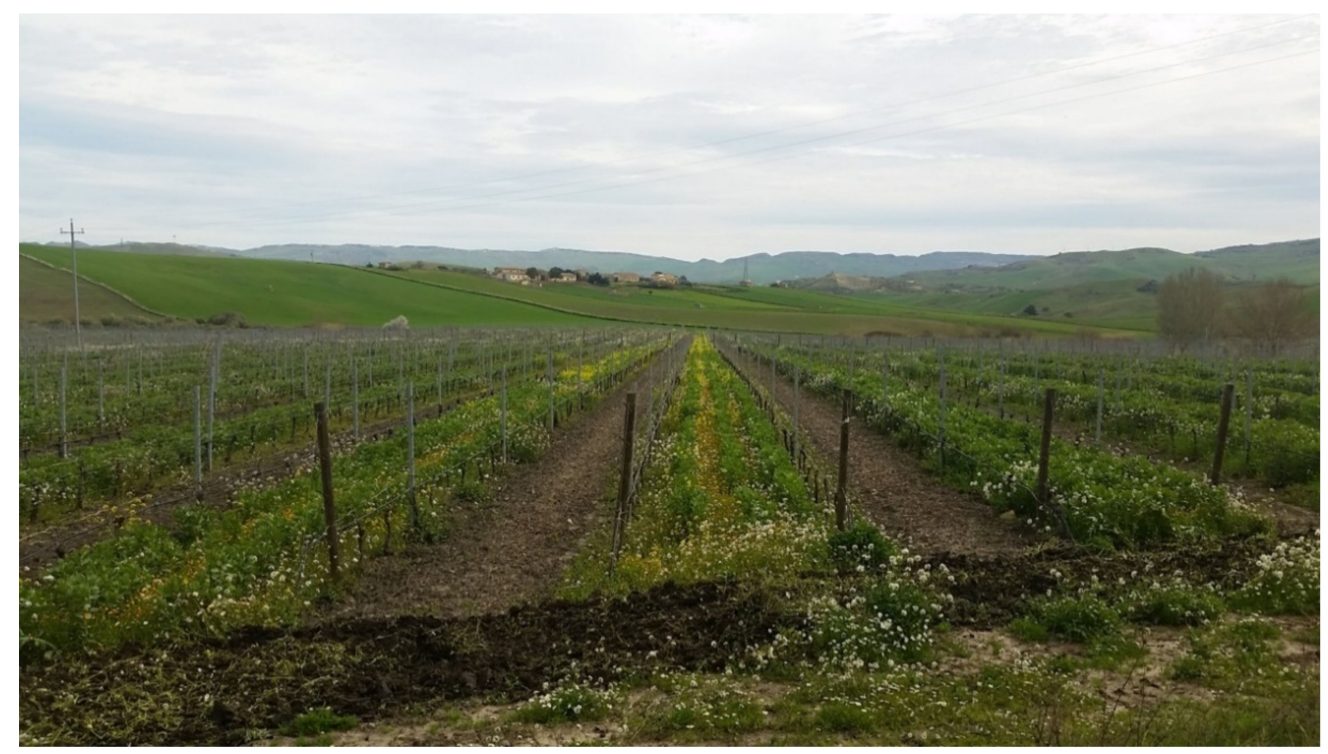

Figure 3. Vineyard with cover crops in alternate rows in Sicily. A mixture of different weeds is frequently used.

Postharvest fruit performance, as related to soil management, is another aspect that has been investigated, evidencing an undoubted influence on shelf life and quality maintenance post-harvest. Wallace [65], reporting the results of a decade of observations, showed that apples derived from grass orchards have a lower $\mathrm{N}$ content than fruits obtained from clean soils, ripen more slowly, and are less prone to physiology disorders during storage and rot. High levels of $\mathrm{N}$, indeed, are correlated with a higher occurrence of Gloeosporium rot (mainly by G. album), which is, instead, reduced in fruits derived from green orchards [66,67]. The higher potassium content, again due to the turf, also reduced product losses due to low temperature breakdown. In a study of Cox and Spartan apples, Perring and Pearson [68] showed that the calcium content in the core of fruits obtained from grassed and irrigated plots was higher than that in fruits from totally weeded plots with a better redistribution of calcium to other tissues during cold storage at $0^{\circ} \mathrm{C}$. The same study found that, in apples prone to calcium deficiency disorders, such as Braeburn, the calcium levels were positively affected by cover crops [69].

\section{Ecosystem Services Affected by Cover Crops}

In 1997, Tilman et al. [4] demonstrated an increase in ecosystem services in complex systems due to increased resource use efficiency. This theory started from the observation of natural systems but has recently landed in the discussion of the sustainability of agroecosystems [70] and the opportunity that adequately designed cover crops have to provide ecosystem services. Although much of the research on cover crops predates the introduction of the concept of "ecosystem services" [8], it is possible to identify as many as 19 ecosystem services in the use of cover crops in perennial woody systems (such as fruit and viticulture). Of these, ten can be defined as regulatory services (beneficial insect conservation, biodiversity support, greenhouse gas $(\mathrm{GHG})$ regulation, nitrate $\left(\mathrm{NO}_{3}\right)$ 
leaching control, pest suppression, pollination support, soil retention improvement, water dynamics regulation, weed suppression, and wildlife habitat provision), seven as support services (arbuscular mycorrhizal fungi, colonization, biomass production, regulation of water dynamics, nitrogen mineralization, nutrient cycling, soil carbon, and soil structure), and three as delivery services (crop yield, economic viability, and knowledge dissemination). Perennial agroecosystems present high variety in terms of species, climate, soil, agronomic techniques adopted, and the duration of planting, as well as, especially for soil management, in terms of plant co-openings with different mixtures.

In the last 10 years, the awareness of climate change issues has increased [71], and the close relationships between the carbon cycle and carbon sequestration have been increasingly integrated in the research on cover crops, turning them into a climate-smart agricultural strategy [72]. Indeed, the combination of a plant cover in the inter-rows of orchards and vineyards with the application of external organic amendments (e.g., compost) or crop residues (e.g., pruning debris) would be a suitable management strategy (Figure 4).

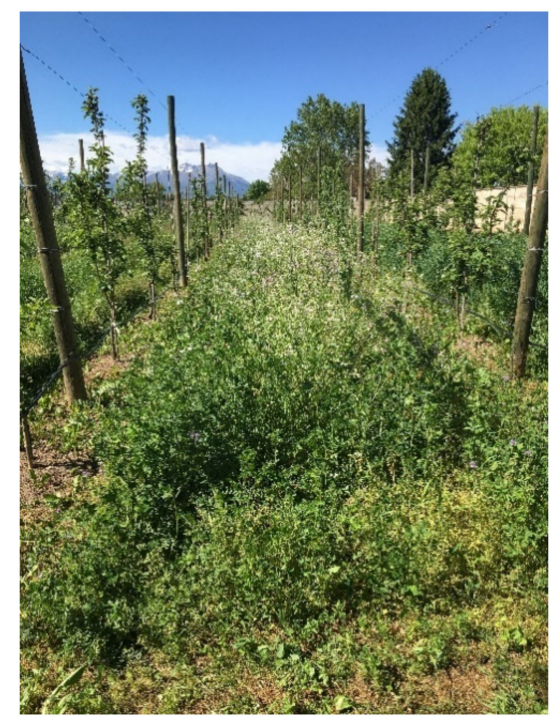

Figure 4. Inter-row green meanure in apple orchard in Piedmont.

Data from the literature [73] reported that cover crops are able to increase soil organic $\mathrm{C}$ stocks, and the sequestration rate appears highest during the first years and progressively decreases as the $C$ stocks approach an equilibrium. In the same way, cover crop research has long focused on integrated pest management (IPM) [74], considering cover crops as a key element in defense strategies to create refuge areas for beneficial insects, as well as hedges and flower strips [75]. In general, the combination of perennial crops and cover crops improves the biotic interactions responsible for pest control through biological control and, more generally, for pollination, which is seen as an ecosystem service for the resilience of rural environments. In other cases, by introducing this new biodiversity, it is possible to start a new ecological process through planting together plants that emit naturally repellent chemicals [76]; Centaurea cyanus, Satureja hortensis, and Ageratum houstonianum in pear orchards can reduce the number of plant-damaging herbivorous pests and increase the abundance of predators and parasitoids [77]. In addition, the positive effects of cover and hedgerow species richness on pollination rates have been demonstrated in fruit orchards [78,79]. Most pollinator species depend on different floral resources [78], also demonstrating the close relationship between flowering plants within and adjacent to apple trees and flower visitation rates by pollinating insects [80].

It is known that the presence of ecological infrastructure near orchards or vineyards can be a useful tool for increasing the agroecosystem biodiversity of cover crops. Buffer strips, together with cover crops, have the potential to maintain wildlife species (e.g., nectar feeders, pollinators, birds, and mammals). The diversity and richness of vegetation in buffer 
areas (such as grass strips or field margins) can positively modify the plant biodiversity within the cultivated area in intensively cultivated agroecosystems, thus enhancing the ecosystem services [81,82].

\section{Conclusions}

An increasing awareness of the ecological relationships established within a fruit orchard can transform weed management into a key strategy for increasing vegetation diversity in agrosystems. Cover crop management can improve soil quality, enhance resource management, suppress weeds, and influence fruit quality characteristics, as well as the habitat for beneficial insects, thus positively influencing pollination, and there is a large amount of scientific evidence for the multifunctional benefits of cover crops in perennial woody systems, even if the cost-benefit aspects have been little investigated.

The main challenge nowadays, is to identify seed mixtures more suitable for these purposes both in terms of type of species and numerosity and balance between different species. As recalled by Creze et al. (2021) [8], although some species of aromatic plants (e.g., Mentha haplocalyx and Indigofera hendecaphylla) are used, for example, for the conservation of beneficial insects, a small number of other species are now used in cover crops. In addition, most of them (Trifolium pratense, Trifolium repens, Trifolium incarnatum, Lolium multiflorum, Festuca arundinacea, Festuca rubra, and Vicia villosa) are used as single species in contrast to the idea of creating complex systems to increase their benefits.

These issues are particularly important today because they are part of the evaluation of agroecological development models, which are part of the European strategies (Farm to Fork and Biodiversity 2030) together with the Sustainable Development Goals of the United Nations. The FAO considers cover crops as one of three solutions for the conservation of agriculture, along with the reduction in tillage and the strengthening of the presence of biodiversity. In this sense, cover crops represent one of the main nature-based solutions that can strongly affect the sustainability of agricultural production, allowing a path of ecological transition (Figure 5).

It is therefore necessary to expand the study of cover crops in many other perennial systems to move towards more sustainable world fruit systems, considering the contribution of plant species and soil health crucial in the fight against climate change.

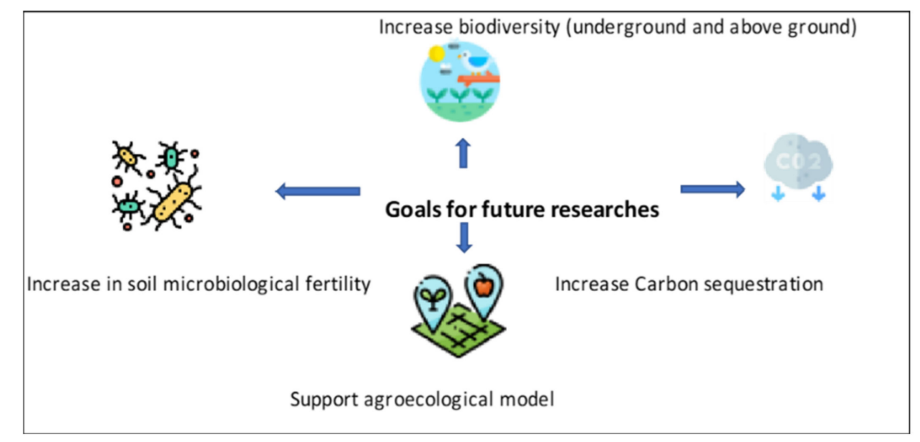

Figure 5. The complex interactions composing the goals for future research.

Author Contributions: Conceptualization, G.G., C.P., D.I. and F.S.; resources, G.G.; writing—original draft preparation, G.G., C.P. and F.S.; writing-review and editing, G.G., C.P., D.I. and F.S. All authors have read and agreed to the published version of the manuscript.

Funding: This research received no external funding.

Institutional Review Board Statement: Not applicable.

Data Availability Statement: Not applicable.

Conflicts of Interest: The authors declare no conflict of interest. 


\section{References}

1. Food and Agriculture Organization; Intergovernmental Technical Panel on Soils. Recarbonizing Global Soils: A Technical Manual of Recommended Management Practices. Cropland, Grassland, Integrated Systems and Farming Approaches-Practices Overview; Food and Agriculture Organization: Rome, Italy, 2021; Volume 3, pp. 2-13. [CrossRef]

2. Pardini, A.; Faiello, C.; Longhi, F.; Mancuso, S.; Snowball, R. Cover crop species and their management in vineyards and olive groves. Adv. Hortic. Sci. 2002, 16, 225-234.

3. Bugg, R.L.; Sarrantonio, M.; Dutcher, J.D.; Phatak, S.C. Understory cover crops in pecan orchards: Possible management systems. Am. J. Alt. Agric. 1991, 6, 50-62. [CrossRef]

4. Tilman, D.; Lehman, C.L.; Thomson, K.T. Plant diversity and ecosystem productivity: Theoretical considerations. Proc. Natl. Acad. Sci. USA 1997, 94, 1857-1861. [CrossRef] [PubMed]

5. Tilman, D.; Reich, P.B.; Isbell, F. Biodiversity impacts ecosystem productivity as much as resources, disturbance, or herbivory. Proc. Natl. Acad. Sci. USA 2012, 109, 10394-10397. [CrossRef]

6. Finney, D.M.; Kaye, J.P. Functional diversity in cover crop polycultures increases multifunctionality of an agricultural system. J. Appl. Ecol. 2017, 54, 509-517. [CrossRef]

7. Smith, R.G.; Atwood, L.W.; Warren, N.D. Increased productivity of a cover crop mixture is not associated with enhanced agroecosystem services. PLoS ONE 2014, 9, e97351. [CrossRef]

8. Crézé, C.M.; Horwath, W.R. Cover Cropping: A Malleable Solution for Sustainable Agriculture? Meta-Analysis of Ecosystem Service Frameworks in Perennial Systems. Agronomy 2021, 11, 862. [CrossRef]

9. Echtenkamp, G.W.; Moomaw, R.S. No-till corn production in a living mulch system. Weed Technol. 1989, 3, 261-266. [CrossRef]

10. Johnston, W.E. Cross sections of a diverse agriculture: Profiles of California's agricultural production regions and principal commodities. In California Agricultural Dimensions and Issues; Siebert, J., Ed.; University of California, Davis, Giannini Foundation: Davis, CA, USA, 2003; pp. 29-55.

11. Campbell, A.J.; Wilby, A.; Sutton, P.; Wackers, F. Do sown flower strips boost wild pollinator abundance and pollination services in a spring-flowering crop? A case study from UK cider apple orchards. Agric. Ecosyst. Environ. 2017, 239, 20-29. [CrossRef]

12. Purvis, B.; Mao, Y.; Robinson, D. Three pillars of sustainability: In search of conceptual origins. Sustain. Sci. 2018, 1, 681-695. [CrossRef]

13. Seager, T.P. The sustainability spectrum and the sciences of sustainability. Bus. Strat. Environ. 2018, 17, 444-453. [CrossRef]

14. Novara, A.; Cerda, A.; Barone, E.; Gristina, L. Cover crop management and water conservation in vineyard and olive orchards. Soil Tillage Res. 2021, 208, 104896. [CrossRef]

15. Demir, Z.; Tursun, N.; Isik, D. Effects of Different Cover Crops on Soil Quality Parameters and Yield in an Apricot Orchard. Int. J. Agric. Biol. 2019, 21, 399-408. [CrossRef]

16. Greenham, D. The environment of the fruit tree: Managing the fruit soils. Sci. Hortic. 1955, 12, $25-31$.

17. Chiusoli, A.; Intrieri, C. "Inerbimento" e permeabilità del terreno negli interfilari di un frutteto. Riv. Ortoflorofruttic. 1966, 50, 342-347.

18. Pou, A.; Gulias, J.; Moreno, M.; Tomas, M.; Medrano, H.; Cifre, J. Cover cropping in Vitis Vinifera, L. CV. Manto negro vineyards under Mediterranean conditions: Effects on plant vigor, yield and grape quality. J. Int. Sci. Vigne. Vin. 2011, 45, 223-234. [CrossRef]

19. Chiusoli, A. Competizioni idriche nei frutteti inerbiti. Riv. Ortoflorofruttic. Ital. 1965, 49, 11-15.

20. White, G.C.; Holloway, R.I.C. The influence of simazine or a straw mulch on the establishment of apple trees in grassed down or cultivated soil. J. Hortic. Sci. 1967, 42, 377-389. [CrossRef]

21. Chiusoli, A. Contributo allo studio della tecnica di "inerbimento" in pescheti adulti. Riv. Ortoflorofruttic. Ital. 1971, 55, 130-135.

22. Stefanelli, D.; Zoppolo, R.J.; Perry, R. Organic orchard floor management systems for apple effect on rootstock performance in the midwestern United States. HortScience 2009, 44, 263-267. [CrossRef]

23. Pisani, P. Effetti dell'«inerbimento» sullo sviluppo degli alberi, sulla loro produttività e sulla qualità dei frutti. Riv. Ortoflorofruttic. Ital. 1965, 49, 28-33.

24. Ali Sarıdaş, M.; Kapur, B.; Çeliktopuz, E.; Şahiner, Y.; Karg1, S.P. Land productivity, irrigation water use efficiency and fruit quality under various plastic mulch colors and irrigation regimes of strawberry in the eastern Mediterranean region of Turkey. Agric. Water Manag. 2021, 245, 106568. [CrossRef]

25. Wang, Y.; Liu, L.; Wang, Y.; Tao, H.; Fan, J.; Zhao, Z.; Guo, Y. Effects of soil water stress on fruit yield, quality and their relationship with sugar metabolism in "Gala" apple. Sci. Hortic. 2019, 258, 108753. [CrossRef]

26. Kodad, O.; Socias, I.; Company, R. Flower age and pollinizer could affect fruit set in late-blooming self-compatible almond cultivars under warm climatic conditions. Sci. Hortic. 2013, 164, 359-365. [CrossRef]

27. Rodrigues, M.A.; Arrobas, M. Cover cropping for increasing fruit production and farming sustainability. In Fruit Crops; Srivastava, A.K., Hu, C., Eds.; Elsevier: Amsterdam, The Netherlands, 2020; pp. 279-295, ISBN 9780128187326. [CrossRef]

28. Sanchez, E.E.; Khemira, H.; Sugar, D.; Righetti, T.L. Nitrogen management in orchards. In Nitrogen Fertilization in the Environment; Bacon, P.E., Ed.; Marcel Dekker Inc.: New York, NY, USA, 1995; pp. 327-380.

29. Wilkinson, B.G. The effect of orchard factors on the chemical composition of apples: I. Some effects of manurial treatment and of grass. J. Hortic. Sci. 1957, 32, 74-84. [CrossRef] 
30. Bould, C.; Hughes, H.M.; Gunn, E. Effects of soil management and NPK fertilisers on tree growth, yield and leaf nutrient composition of dessert apples. Exp. Hortic. 1972, 24, 25-36.

31. Haynes, R.J. Some observations on the effect of grassing-down, nitrogen fertilisation, and irrigation on the growth, leaf nutrient content and fruit quality of young golden delicious apple trees. J. Sci. Food Agric. 1981, 32, 1001-1013. [CrossRef]

32. Tagliavini, M.; Tonon, G.; Scandellari, F.; Quinones, A.; Palmieri, S.; Menarbin, G.; Gioacchini, P.; Masia, A. Nutrient recycling during the decomposition of apple leaves (Malus domestica) and mowed grasses in an orchard. Agric. Ecosyst. Environ. 2017, 118, 191-200. [CrossRef]

33. Giese, G.; Velasco-Cruz, C.; Roberts, L.; Heitman, J.; Wolf, T.K. Complete vineyard floor cover crops favorably limit grapevine vegetative growth. Scientia horticulturae 2014, 170, 256-266. [CrossRef]

34. Motisi, A.; Pernice, F.; Sottile, F.; Caruso, T. Rootstock effect on stem water potential gradients in cv. "armking" nectarine trees. Acta Hortic. 2004, 658, 75-79. [CrossRef]

35. Aras, S.; Keles, H.; Bozkurt, E. Physiological and histological responses of peach plants grafted onto different rootstocks under calcium deficiency conditions. Sci. Hortic. 2021, 281, 109967. [CrossRef]

36. Szalay, L.; Bakos, J.; Tósaki, Á.; Keleta, B.T.; Froemel-Hajnal, V.; Karsai, I. A 15-yearlong assessment of cold hardiness of apricot flower buds and flowers during the blooming period. Sci. Hortic. 2021, 290, 110520. [CrossRef]

37. Thapa, V.R.; Ghimire, R.; Acosta-Martínez, V.; Marsalis, M.A.; Schipanski, M.E. Cover crop biomass and species composition affect soil microbial community structure and enzyme activities in semiarid cropping systems. Appl. Soil 2021, 157, 103735. [CrossRef]

38. Bould, C.; Jarrett, R.M. The effect of cover crops and NPK fertilizers on growth, crop yield and leaf nutrient status of young dessert apple trees. J. Hortic. Sci. 1962, 37, 58-82. [CrossRef]

39. Goode, J.E.; Hyrycz, K.J. The effect of nitrogen on young, newly-planted, apple rootstocks in the presence and absence of grass competition. J. Hortic. Sci. 1976, 51, 321-327. [CrossRef]

40. Hipps, N.A.; Davies, M.J.; Johnson, D.S. Effects of different ground vegetation management systems on soil quality, growth and fruit quality of culinary apple trees. J. Hortic. Sci. Biotechnol. 2004, 79, 610-618. [CrossRef]

41. Raese, J.T. Response of young 'd'Anjou' pear trees to triazine and triazole herbicides and nitrogen. J. Am. Soc. Hortic. Sci. 1976, $102,215-218$.

42. Tworkoski, T.J.; Glenn, D.M. Long-term effects of managed grass competition and two pruning methods on growth and yield of peach trees. Sci. Hortic. 2010, 126, 130-137. [CrossRef]

43. Hipps, N.A.; Samuelson, T.J. Effects of long-term herbicide use, irrigation and nitrogen fertiliser on soil fertility in an apple orchard. J. Sci. Food Agric. 1991, 55, 377-387. [CrossRef]

44. Sweet, R.M.; Schreiner, R.P. Alleyway cover crops have little influence on Pinot noir grapevines (Vitis vinifera L.) in two western Oregon vineyards. Am. J. Enol. Vitic. 2010, 61, 240-252.

45. Mercenaro, L.; Nieddu, G.; Pulina, P.; Porqueddu, C. Sustainable management of an intercropped Mediterranean vineyard. Agriculture Ecosyst. Env. 2014, 192, 95-104. [CrossRef]

46. Mia, M.J.; Massetani, F.; Murri, G.; Facchi, J.; Monaci, E.; Amadio, L.; Neri, D. Integrated weed management in high density fruit orchards. Agronomy 2020, 10, 1492. [CrossRef]

47. Gormley, R.; Robinson, D.; O'Kennedy, N. The effects of soil management systems on the chemical composition and quality of apples. II. Cox's Orange Pippin and Red Jonathan apples. J. Sci. Food Agric. 1973, 24, 241-247. [CrossRef]

48. Atkinson, J.; Taylor, L.; Taylor, J.M.; Lucas, A.S. Temperature and irrigation effects on the cropping, development and quality of "Cox's Orange Pippin" and "Queen Cox" apples. Sci. Hortic. 1998, 75, 59-81. [CrossRef]

49. Gormley, R.; Robinson, D.; O’Kennedy, N. The effects of soil management systems on the chemical composition and quality of apples I. Golden Delicious apples. J. Sci. Food Agric. 1973, 24, 227-239. [CrossRef]

50. Stevenson, D.S.; Neilsen, G.H.; Cornelson, A. The effect of woven plastic mulch, herbicides, grass sod, and nitrogen on 'Foch' grapes under irrigation. HortScience 1986, 21, 439-441.

51. Cavender, G.; Liu, M.; Hobbs, D.; Frei, B.; Strik, B.; Zhao, Y. Effects of different organic weed management strategies on the physicochemical, sensory, and antioxidant properties of machine-harvested blackberry fruits. J. Food Sci. 2014, 79, S2107-S2116. [CrossRef]

52. Guerra, B.; Steenwerth, K. Influence of floor management technique on grapevine growth, disease pressure, and juice and wine composition: A review. Am. J. Enol. Vitic. 2012, 63, 149-164. [CrossRef]

53. Scalabrelli, G.; Ferroni, G.; Boselli, M.; Bandinelli, R.; Mancuso, S. L'inerbimento del vigneto in Toscana. Atti del convegno XXIV Momevi sulla gestione del suolo in viticoltura. Not. Tec. 1999, 58, $43-63$.

54. Coniberti, A.; Ferrari, V.; Disegna, E.; Dellacassa, E.; Lakso, A.N. Under-trellis cover crop and deficit irrigation to regulate water availability and enhance Tannat wine sensory attributes in a humid climate. Sci. Hortic. 2018, 235, 244-252. [CrossRef]

55. Van Huyssteen, L.; Weber, H.W. The effect of selected minimum and conventional tillage practices in vineyard cultivation on vine performance. S. Afr. J. Enol. Vitic. 1980, 1, 77-83. [CrossRef]

56. Colugnati, G.; Cattarossi, G.; Crespan, G. L'inerbimento nel vigneto moderno. Inf. Agrar. 2006, 10, 53-65.

57. Luzzini, G.; Slaghenaufi, D.; Pasetto, F.; Ugliano, M. Influence of grape composition and origin, yeast strain and spontaneous fermentation on aroma profile of Corvina and Corvinone wines. LWT 2021, 143, 111120. [CrossRef] 
58. Wu, Y.S.; Zhang, Y.M.; Ji, X.H.; Zhang, R.; Liu, D.L.; Zhang, Z.Y.; Li, W.Y.; Chen, X.S. Effects of natural grass on soil nutrient, enzyme activity and fruit quality of pear orchard in Yellow River Delta. Sci. Agric. Sin. 2013, 46, 99-108.

59. Marsh, K.B.; Daly, M.J.; McCarthy, T.P. The effect of understorey managment on soil fertility, tree nutrition, fruit production and apple fruit quality. Biol. Agric. Hortic. 1996, 13, 161-173. [CrossRef]

60. Perring, M.A. The effect of orchard factors on the chemical composition of apples IV. Some effects of soil management and NPK fertilizers. J. Hortic. Sci. 1975, 50, 425-433. [CrossRef]

61. White, K.E.; Brennan, E.B.; Cavigelli, M.A. Soil carbon and nitrogen data during eight years of cover crop and compost treatments in organic vegetable production. Data Brief 2020, 33, 106481. [CrossRef]

62. Wheeler, S.J.; Pickering, G.J. The effects of Soil Management Techniques on Grape and Wine Quality. Fruits. Growth, Nutrition and Quality; WFL Publisher: Helsinki, Finland, 2006; pp. 195-208.

63. Muscas, E.; Cocco, A.; Mercenaro, L.; Cabras, M.; Lentini, A.; Porqueddu, C.; Nieddu, G. Effects of vineyard floor cover crops on grapevine vigor, yield, and fruit quality, and the development of the vine mealybug under a Mediterranean climate. Agric. Ecosyst. Environ. 2017, 237, 203-212. [CrossRef]

64. Bouzas-Cid, Y.; Portu, J.; Pérez-Álvarez, E.P.; Gonzalo-Diago, A.; Garde-Cerdán, T. Effect of vegetal ground cover crops on wine anthocyanin content. Sci. Hortic. 2016, 211, 384-390. [CrossRef]

65. Wallace, T. Some effects of orchard factors on the quality and storage properties of apples. In Science and Fruit; University of Bristol: Bristol, UK, 1953; pp. 140-161.

66. Montgomery, H.B.S.; Wilkinson, B.G.; Edney, K.L. Storage experiments with Cox's Orange Pippin apples from a manurial trial. J. Hortic. Sci. 1962, 37, 150-158. [CrossRef]

67. Gulbagca, F.; Burhan, H.; Elmusa, F.; Sen, F. Calcium nutrition in fruit crops: Agronomic and physiological implications. In Fruit Crops; Srivastava, A.K., Hu, C., Eds.; Elsevier: Amsterdam, The Netherlands, 2020; pp. 173-190. [CrossRef]

68. Perring, M.A.; Pearson, K. Redistribution of minerals in apple fruit during storage: Effects of storage temperature, varietal differences, and orchard management. J. Sci. Food Agric. 1986, 37, 607-617. [CrossRef]

69. Musacchi, S.; Serra, S. Apple fruit quality: Overview on pre-harvest factors. Sci. Hortic. 2018, 234, 409-430. [CrossRef]

70. Florence, A.M.; Highley, L.G.; Drijber, R.A.; Francis, C.A.; Lindquist, J.L. Cover crop mixture diversity, biomass productivity, weed suppression and stability. PLoS ONE 2019, 14, e0206195. [CrossRef]

71. Zilberman, D.; Lipper, L.; McCarthy, N.; Gordon, B. Innovation in response to climate change. Nat. Resour. Manag. Policy 2018, 52, 49-74.

72. Vicente-Vicente, J.L.; Garcia-Ruiz, R.; Francaviglia, R.; Aguilera, E.; Smith, P. Soil carbon sequestration rates under Mediterranean woody crops using recommended management practices: A meta-analysis. Agric. Ecosyst. Environ. 2016, 235, 204-214. [CrossRef]

73. Blanco-Canqui, H.; Shaver, T.M.; Lindquist, J.L.; Shapiro, C.A.; Elmore, R.W.; Francis, C.A.; Hergert, G.W. Cover crops and ecosystems services: Insights from studies in temperate soils. Agron. J. 2015, 107, 2449-2474. [CrossRef]

74. Sansavini, S. The role of research and technology in shaping a sustainable fruit industry: European advances and prospects. Rev. Bras. Frutic. 2006, 28, 550-558. [CrossRef]

75. Sasanelli, N.; Konrat, A.; Migunova, V.; Toderas, I.; Iurcu-Straistaru, E.; Rusu, S.; Bivol, A.; Andoni, C.; Veronico, P. Review on Control Methods against Plant Parasitic Nematodes Applied in Southern Member States (C Zone) of the European Union. Agriculture 2021, 11, 602. [CrossRef]

76. Parolin, P.; Bresch, C.; Desneux., N.; Brun, R.; Bout, A.; Boll, R.; Poncet, C. Secondary plants used in biological control: A review. Int. J. Pest. Manag 2012, 58, 91-100. [CrossRef]

77. Song, B.; Wu, H.; Kong, Y.; Zhang, J.; Du, Y.; Hu, J.; Yao, Y. Effects of intercropping with aromatic plants on the diversity and structure of an arthropod community in a pear orchard. BioControl 2010, 55, 741-751. [CrossRef]

78. Miñarro, M.; Prida, E. Hedgerows surrounding organic apple orchards in north-west Spain: Potential to conserve beneficial insects. Agric. For. Entomol 2013, 15, 382-390. [CrossRef]

79. Nicholls, C.; Altieri, M. Plant biodiversity enhances bees and other insect pollinators in agroecosystems. A review. Agron Sustain. Dev. 2013, 33, 257-274. [CrossRef]

80. Samnegård, U. Management trade-offs on ecosystem services in apple orchards across Europe: Direct and indirect effects of organic production. J. Appl. Ecol. 2019, 56, 802-811. [CrossRef]

81. Hahn, M.; Lenhardt, P.P.; Brühl, C.A. Characterization of field margins in intensified agro-ecosystems-Why narrow margins should matter in terrestrial pesticide risk assessment and management. Integr. Enviro. Assess. Manag. 2014, 10, 456-462. [CrossRef]

82. Mania, E.; Isocrono, D.; Pedullà, M.L.; Guidoni, S. Plant diversity in an intensively cultivated vineyard agro-ecosystem (Langhe, North-West Italy). S. Afr. J. Enol. Vitic. 2015, 36, 378-388. 